\title{
Type IV Collagen Staining Method
}

National Cancer Institute

\section{Source}

National Cancer Institute. Type IV Collagen Staining Method. NCI Thesaurus. Code C122838.

An immunohistochemical technique used to detect the presence of type IV collagen in a tissue sample. 